Semina $\square \quad \mathrm{Nr} 14$

Scientiarum 2015

s. $92-119$

DOI: http://dx.doi.org/10.15633/ss.1081

Iwona Kleszcz

Marek Jakubiec

\title{
Considerations on Legal and Philosophical Problems in Experimental Botany: The case of plant in vitro cultures
}

The main inquiry of the present paper is as follows: is it necessary to consider the introduction of legal restrictions concerning the scintific experiments on plants for which model examples are in vitro cultures? In answering such question, it is unavoidable to deliberate whether there is any axiological basis for such norms. Therefore, an answer to the "legal question" is determined by a proper understanding of the "philosophical (axiological)" one. Furthermore, any attempt at solving these issues cannot be valid without professional biological insight into the character of experimental procedures. Otherwise, it will be only a kind of speculation.

For these reasons, the structure of the paper consists of two parts. In the first part, the selected issues of biological procedure of plant in vitro cultures are analyzed from a perspective of laboratory practice. The second part presents the character of both actual legal regulations and possible de lege ferenda postulations in the context of philosophical dilemmas that are encountered while analyzing these experimental issues.

The philosophical and legal problems involved in plant in vitro cultures have been already been relatively rarely investigated in the proposed way. What is of great relevance is that the case of genetically modified plants is not raised in the paper. 
The present essay is written by two $\mathrm{PhD}$ students: the first in biology, ${ }^{1}$ and the second in both philosophy and law. ${ }^{2}$ It analyzes issues relevant to scholars doing research in their respective areas of study.

\section{Biological Experiments: The case of in vitro cultures}

\subsection{Plant cells are totipotent}

Plant cells have an unlimited capacity to grow and develop. ${ }^{3}$ This means that not only young, undifferentiated but also many mature cells (with some exceptions) are totipotent so they have an ability to resume mitotic divisions, then differentiate into other cell types and finally regenerate whole plant bodies. ${ }^{4}$ Therefore it is an important phenomenon in the natural world. Such a capability is lost by most of animal cells shortly after the embryonic phase. ${ }^{5}$

The totipotency of many differentiated (somatic) cells is especially apparent when plant tissue or cells are disturbed or removed from their natural environment. Isolating and placing pieces of the plant under control conditions, for example, on artificial media in a tissue culture may cause an initiation of the cells' division activity. It is accompanied by an expression of some previous blocked genes involved in reaching a certain path of development. As a result, a new plant organism can be formed. ${ }^{6}$

1 Iwona Kleszcz, Department of Plant Cytology and Embryology, Institute of Botany, Jagiellonian University.

2 Marek Jakubiec, Department for Philosophy of Law and Legal Ethics, Faculty of Law and Administration, Jagiellonian University; Department for Philosophy of Nature, Faculty of Philosophy, Pontifical University in Krakow.

3 See: I. M. Sussex, The Scientific Roots of Modern Plant Biotechnology, "The Plant Cell" vol. 20 (2008) 5, p. 1189-1198.

4 See: A. Tretyn, Podstawy strukturalno-funkcjonalne komórki roślinnej, [in:] Fizjologia roślin, red. J. Kopcewicz, S. Lewak, Warszawa 2012, p. 22-84; See: A. Bach, B. Pawłowska, Procesy rozwojowe $w$ kulturach in vitro i typy kultury, [in:] Biotechnologia roślin, red. S. Malepszy, Warszawa 2009, p. 21-40.

5 A. Tretyn, Podstawy strukturalno-funkcjonalne komórki roślinnej, op. cit.

6 See: J. R. Gorst, The Concept of Totipotency, [in:] Plants in Action. Adaptation in Nature, Performance in Cultivation, ed. B. J. Atwell, P. E. Kriedemann, 
The totipotency of somatic cells may be revealed in the next generations. To induce this process, the proper conditions that stimulate cells to division, differentiation and growth should be provided. ${ }^{7}$ Plant in vitro cultures can fulfill this role.

\subsection{Plant in vitro cultures - general information}

Plant in vitro cultures include many processes that are related to the maintenance and development of growing plant materials under laboratory conditions. ${ }^{8}$ The most important aspects of plant tissue cultures are briefly described below.

\subsubsection{Short historical note}

A desire to understand how plants grow and develop under controlled conditions was the main reason why plant tissue cultures began to be formed in the second part of the 19th century. ${ }^{9}$

In 1898, Gottlieb Haberlandt, an Austrian botanist, was the first person to culture single isolated fully differentiated leaf cells on salt solution with an addition of sucrose. ${ }^{10}$ Those isolated cells were maintained alive for long-drawn periods of time, but they failed to divide. Haberlandt's aim was to lead cells into continued division, but this aim could be obtained only after the discovery of auxins, one of the most important plant growth regulators. ${ }^{11}$

C. G. N. Turnbull, Melbourne 1999, http://plantsinaction.science.uq.edu.au/edition1/?q=content/10-2-1-concept-totipotency (17.03.2015); A. Tretyn, Podstawy strukturalno-funkcjonalne komórki roślinnej, op. cit.

7 A. Tretyn, Podstawy strukturalno-funkcjonalne komórki roślinnej, op. cit.

8 See: A. Adamczuk, I. Siegień, I. Ciereszko, Morphogenesis of Plants in vitro under Stress Conditions, [in:] Biological Diversity - from Cell to Ecosystem, ed. G. Łaska, Białystok 2012, p. 25-40.

9 See: H. R. Dagla, Plant Tissue Culture. Historical Developments and Applied Aspects, "Resonance" vol. 17 (2012) 8, p. 759-767.

10 See: S. S. Bhojwani, M. K. Razdan, Plant Tissue Culture: Theory and Practice, a Revised Edition, New Delhi 2004, p. 3.

11 See: J. H. Harrison, Foreword, [in]: Experiment in Plant Tissue Culture, ed. J. H. Dodds, L. W. Roberts, New York 1985, p. VII. 
At the beginning of the $20 \mathrm{~h}$ century, research studies on plant tissue cultures were continued alongside an improvement of aseptic working methods and discoveries of auxins mentioned above as well as a need of B vitamins for tissue growth. ${ }^{12}$ By the early 1930s, the first successful plant in vitro culture experiment was conducted by White (1934), who established the culture of isolated tomato roots under sterile conditions in which plant cells continued their growth and division processes. ${ }^{13}$ Later, Ball (1946) received whole plants by their shoot meristem culture. ${ }^{14}$

Skoog and Miller made a very important discovery in the history of plant in vitro cultures in 1957. They found that plants organ formation is controlled by hormones where a meaningful role has a ratio of auxins to cytokinins. ${ }^{15}$ Later in 1962, Murashige and Skoog published a composition of their very famous and commonly used to these days plant tissue culture medium (abbreviated 'MS' because of its authors). ${ }^{16}$

In Poland, the first experiments on plant in vitro cultures were initiated by Jerzy Czosnowski in the middle of the 20th century. Then, Maciej Zenkteler initiated and developed experimental embryology studies in Poznań. The city and the Adam Mickiewicz University started to become a center of in vitro culture research and it has influenced other Polish institutions. ${ }^{17}$

12 H. R. Dagla, Plant Tissue Culture. Historical Developments and Applied Aspects, op. cit.

13 I. M. Sussex, The Scientific Roots of Modern Plant Biotechnology, op. cit.

14 E. Ball, Development in Sterile Culture of Stem Tips and Subjacent Regions of Tropaeolum majus L. and of Lupinus albus L., "American Journal of Botany" vol. 33 (1946) 5, p. 301-318.

15 F. Skoog, C. O. Miller, Chemical Regulation of Growth and Organ Formation in Plant Tissues Cultured in vitro, "Symposia of the Society for Experimental Biology" vol. 11 (1957), p. 118-130.

16 T. Murashige, F. Skoog, A Revised Medium for Rapid Growth and Bio-Sssays with Tobacco Tissue Cultures. "Physiologia Plantarum", vol. 15 (1962), p. 473-497.

17 M. Zenkteler, E. Zenkteler, 65 years of in vitro Culture in Poland, "Acta Societatis Botanicorum Poloniae”, vol. 82 (2013) 3, p. 183-192. 


\subsubsection{How to initiate tissue culture?}

The first step in initiating in vitro cultures are connected with choosing the right explants, which are small organs or pieces of plant tissue. They are dependent on the kind of the culture to be initiated and the purposes of the planned experiment different parts of the mother plant are used. It can be just a cell, piece of a tissue, or an organ. A correct choice of parental material, e.g. immature tissues with capability to differentiation and cell division, is of a great importance in determining the success of the experiment. ${ }^{18}$

Because culture conditions are favorable for the growth and development of microorganisms, plant in vitro cultures must be fixed and maintained in sterile conditions. ${ }^{19}$ Microbial organisms, especially bacteria and fungi, compete for living factors, e.g. space and nourishment with plant material growing in vitro. Therefore, a source of explants before the culture is treated in solution containing disinfectant. Also, synthetic media, vessels and tools used for dissection must be sterilized to minimize infections in the culture. ${ }^{20}$

\subsubsection{The culture environment}

Plant cells, tissues or organs isolated from the parental plant are placed on artificial media in sterile environment. Light, temperature, humidity and atmosphere compositions (especially the ratio of oxygen to carbon dioxide to ethylene) are important factors that have to be controlled during the culture. ${ }^{21}$

18 M. L. Christianson, D. A. Warnick, Temporal Requirement for Phytohormone Balance in the Control of Organogenesis in vitro, "Developmental Biology" vol. 112 (1985), p. 494-497; E. F. George, Plant Tissue Culture Procedure-Background, [in:] Plant Propagation by Tissue Culture, 3rd Edition, Volume 1. The Background, ed. E. F. George, M. A. Hall, G.-J. de Klerk, The Netherlands 2008, p. 1-28.

19 E. F. George, Plant Tissue Culture Procedure-Background, op. cit.

20 A. C. Cassells, B. M. Doyle, Pathogen and Biological Contamination Management: the Road Ahead, [in:] Plant Cell Culture Protocols, ed. V. M. Loyola-Vargas, F. Vázquez-Flota, New York 2005, p. 35-50.

${ }_{21}$ T. Kozai, C. Kubota, B. R. Jeong, Environmental Control for the Large-Scale Production of Plants through in vitro Techniques, "Plant Cell, Tissue and Organ 
Depending on the species, each of the parameters mentioned above should be optimized. The roper selection of media, the establishment of physical factors during the culture and the right choice of the maternal plant all decide together about the way and rate of the explants' development. The acidity of medium together with the size and shape of the vessels, which influence the intensity of gas exchange between explants and the environment, used during the experiment are also important. ${ }^{22}$

\subsubsection{Media and their components}

At the beginning of the plant tissue, culture explants are placed on artificial media. The medium is a solution of macro- and micronutrients and carbon source (commonly sucrose) necessary for plant material growth and development. ${ }^{23}$ It can also be supplemented by other substances depending on the type of the culture, such as various amino acids and vitamins. ${ }^{24}$ The media also contain plant growth regulators that have modifying influence on plant morphogenesis at very low concentrations. ${ }^{25}$

Explants can be cultured both in a liquid and solidified medium with a gelling substance. The type of medium used during the culture depends on the type of the experiment and our plant material. Explants that are placed on solid media are maintained static,

Culture (PCTOC)” vol. 51 (1997) 1, p. 49-56; E. F. George, Plant Tissue Culture Procedure-Background, op. cit.

22 A. Bach, B. Pawłowska, Procesy rozwojowe $w$ kulturach in vitro i typy kultury, op. cit.

${ }^{23}$ A. Bach, B. Pawłowska, Procesy rozwojowe $w$ kulturach in vitro i typy kultury, op. cit.

24 E. F. George, G-J. de Klerk, The Components of Plant Tissue Culture Media I : Macro- and Micro-Nutrients, [in:] Plant Propagation by Tissue Culture, op. cit., p. 65-114; T. Thorpe, C. Stasolla, E. C. Yeung, G-J. de Klerk, A. Roberts, E. F. George, The Components of Plant Tissue Culture Media II : Organic Additions, Osmotic and pH Effects, and Support Systems, [in:] Plant Propagation by Tissue Culture, op. cit., p. 115-174.

25 I. Machakova, E. Zazimalova, E. F. George, Plant Growth Regulators I: Introduction; Auxins, their Analogues and Inhibitors, [in:] Plant Propagation by Tissue Culture, op. cit., p. 175-205. 
which means that they are cultured in simple vessels where only their lower surface touches the medium. Liquid media are used for suspension cultures where, for example, productions of secondary metabolites are analyzed. ${ }^{26}$

Plant tissue culture might be established for long periods of time. Putting explants onto fresh media, which is called subculturing, plays a role in the culture continuity. ${ }^{27}$

\subsubsection{Plant growth regulators}

Plants as well as animals have compounds, known as hormones, which naturally occur within their tissues and are active at very low concentrations. Plant hormones (also called plant growth substances) have a regulatory role in the process of development and growth. Some of them can be prepared synthetically and then used in in vitro cultures. Those are called plant growth regulators (PGRs) and have the same physiological activities as naturally occurring substances. ${ }^{28}$ Their usage is more popular because of their lower price and greater commercial availability. ${ }^{29}$

Plant hormones are classified into five groups: auxins, cytokonins, gibberellins, abscisic acid, and ethylene. In in vitro cultures, auxins and cytokinins are the most important. Cytokinins stimulate cell divisions, while auxins are responsible both for regulating growth and cell divisions. ${ }^{30}$ General rule says that high concentration of auxins stimulate the process of root formation (rhizogenesis), while high levels of cytokinins determine formation, proliferation and shoots development (caulogenesis). Combinations of PGRs and

26 E. F. George, Plant Tissue Culture Procedure-Background, op. cit.

27 E. F. George, Plant Tissue Culture Procedure - Background, op. cit.

28 I. Machakova, E. Zazimalova, E. F. George, Plant Growth Regulators I: Introduction; Auxins, their Analogues and Inhibitors, op. cit.

29 A. Bach, B. Pawłowska, Procesy rozwojowe $w$ kulturach in vitro i typy kultu$r y$, op. cit.

${ }^{30}$ K. Matysiak, K. Adamczewski, Regulatory wzrostu i rozwoju roślin-kierunki badań w Polsce $i$ na świecie, „Progress in Plant Protection” vol. 49 (2009) 4, p. 1810-1816. 
differentiation of their content in a used medium can cause various effects of the planned culture. ${ }^{31}$

\subsubsection{Stress in in vitro cultures}

It is well known that in vitro culture conditions are stress conditions. The process of plant material sterilization where disinfectant solution is used, cutting of plant materials and then placing explants in culturing vessels are first critical factors under plant in vitro cultures. It is just the beginning of plant material exposure to the other stressful elements that together influence its subsequent growth and development. Like under natural conditions, plants have to cope with such things.

Stressful factors under in vitro cultures are divided into four groups: mechanical, physical, chemical, and biological. Mechanical ones include wounds and injuries during subculturing the explants. Different levels of physical elements, such as concentration of gases (mainly oxygen, carbon dioxide, ozone and ethylene), acidity or alkalinity of a solution, temperature, humidity and hydration, influence together culturing plant materials. The same meanings have chemical factors like the concentration of plant growth regulators and the mineral composition of the medium. From a biological point of view, any visible or invisible infections are stressful for explants as well. ${ }^{32}$

The above-mentioned plant materials' reactions to the elements mentioned above differ between culturing species. Stress conditions may have a destructive or constructive role during conducted experiments. ${ }^{33}$ They are connected with an increase in the production of chemical molecules called reactive oxygen species (ROS). They play

31 A. Bach, B. Pawłowska, Procesy rozwojowe $w$ kulturach in vitro i typy kultury, op. cit.

32 A. Bach, B. Pawłowska, Procesy rozwojowe $w$ kulturach in vitro i typy kultury, op. cit.

${ }^{33}$ A. Adamczuk, I. Siegień, I. Ciereszko, Morphogenesis of Plants in vitro under Stress Conditions, op. cit. 
a role as signaling molecules during many physiological processes. ${ }^{34}$ The overproduction of ROS may damage plant cell membranes and their other components; inhibit the process of growth; and finally cause the plants' death. ${ }^{35}$ On the other hand, the high level of ROS might be beneficial for the process of plant regeneration under in vitro cultures. ${ }^{36}$

Thus various treatments covering the manipulating of culture conditions can be used to optimize plant in vitro morphogenesis. ${ }^{37}$

\subsubsection{Plant in vitro morphogenesis}

Under natural conditions, plants usually form seeds as a result of the generative process of reproduction. Inside the seed, the embryo, which emerges from a zygote (a fertilized egg) after a sequence of mitosis divisions, has the message of how to reconstitute whole plant body similar to parental organisms with the same structure, shape, and function. The new biological organization of form with determined structure and function is known as morphogenesis. ${ }^{38}$

Morphogenesis in plants is a complicated phenomenon; many aspects of it are not yet known in detail. Considering this process in the context of plant in vitro cultures, discoveries of cell totipotency, ${ }^{39}$

${ }_{34}$ I. Ślesak, M. Libik, B. Karpińska, S. Karpiński, Z. Miszalski, The Role of Hydrogen Peroxide in Regulation of Plant Metabolism and Cellular Signalling in Response to Environmental Stresses, "Acta Biochimica Polonica" vol. 54 (2007), p. 39-50.

35 A. Adamczuk, I. Siegień, I. Ciereszko, Morphogenesis of Plants in vitro under Stress Conditions, op. cit.

${ }_{36}$ R. K. Jain, S. Jain, R. Wu, Stimulatory Effect of Water Stress on Plant Regeneration in Aromatic Indica rice varieties, "Plant Cell Reports" vol. 15 (1996), p. 449454; I. Haq, Z. Chang-Xing, Z. Mukhtar, C. A. Jaleel, M. M. Azooz, Effect of Physical Desiccation on Plant Regeneration Efficiency in Rice (Oryza sativa L.) Variety super basmati, "Journal of Plant Physiology" vol. 166 (2009), p. 1568-1575.

37 H. K. Khanna, G. E. Daggard, Enhanced of Shoot Regeneration in Nine Australian Wheat Cultivars by Spermidine and Water Stress Treatments, "Australian Journal of Plant Physiology" vol. 28 (2001), p. 1243-1247; S. Puijalon, F. Piola, G. Bornette, Abiotic Stresses Increase Plant Regeneration Ability, "Evolutionary Ecology” vol. 22 (2008), p. 493-506; A. Adamczuk, I. Siegień, I. Ciereszko, Morphogenesis of Plants in vitro under Stress Conditions, op. cit.

38 A. Tretyn, Podstawy strukturalno-funkcjonalne komórki roślinnej, op. cit.

39 M. J. Schleiden, Beiträge zur Phytogenesis, Berlin 1838, p. 137-176 (Archiv für Anatomie, Physiologie und Wissenschaftliche Medicin, von. J. Müller); T. Schwann, 
the occurrence of plant hormones ${ }^{40}$ and the hypothesis of their meaningful role in this event ${ }^{41}$ have led to its better understanding.

In in vitro cultures, morphogenesis can be obtained in many ways. One, termed as organogenesis, is the new origin of organs, either roots or shoots from cultured explants. Organogenesis has two forms: direct and indirect. Indirect organogenesis is characterized by plant structure formation via callus tissue. Direct organogenesis omits this step: the callus is not induced, and plants structures are formed directly from explants. ${ }^{42}$

A valid kind of plant in vitro morphogenesis is somatic embryogenesis in which embryos are formed from cultured somatic cells. Nonetheless, it is a vegetative type of plant reproduction. In determined conditions, each living cell may purchase an embryogenic competence. ${ }^{43}$

The above-mentioned induction of plant in vitro morphogenesis depends on the kind of explants, media composition, and culture conditions.

1.2.8. Callus - the type of plant tissue valid in particular under in vitro cultures

The callus is an undifferentiated or poorly differentiated tissue whose formation is induced by stress: pathogen infection or wounding a plant. ${ }^{44}$ This tissue might be produced from a single differentiated cell. ${ }^{45}$

Mikroscopische Untersuchungen über die Übereinstimmung in der Struktur und dem Wachstum des Thiere und Pflanzen, von W. Engelmann, Leipzig 1839, n. 176.

40 M. L. Christianson, D. A. Warnick, Temporal Requirement for Phytohormone Balance in the Control of Organogenesis in vitro, op. cit.

${ }^{41}$ F. Skoog, C. O. Miller, Chemical Regulation of Growth and Organ Formation in Plant Tissues Cultured in vitro, op. cit.

42 G. C. Phillips, In vitro morphogenesis in plants - recent advances, "In Vitro Cellular \& Developmental Biology - Plant” vol. 40 (2004), p. 342-345.

43 A. Bach, B. Pawłowska, Procesy rozwojowe w kulturach in vitro i typy kultury, op. cit.

${ }^{4}$ A. Bach, B. Pawłowska, Procesy rozwojowe $w$ kulturach in vitro i typy kultury, op. cit.; M. Ikeuchi, K. Sugimoto, A. Iwase, Plant Callus: Mechanisms of Induction and Repression, "The Plant Cell”, vol. 25 (2013), p. 3159-3173.

45 F. C. Steward, M. O. Mapes, K. Mears, Growth and Organized Development of Cultured Cells. II. Organization in Cultures Grown from Freely Suspended Cells, 
Callus cells have various shapes and sizes, and because many of them have totipotent character, they can differentiate into meristem cells that divide intensively and form meristem centers. At these places, the process of organogenesis can start and the whole plants body can be regenerated. ${ }^{46}$

In in vitro cultures, the callus is formed when cut-off explants are placed on experimental media mostly within an intermediate ratio of cytokinins and auxins or other PGR additions, such as abscisic acid, under suitable conditions. ${ }^{47}$

From the moment of the discovery, the callus regeneration system the tissue has been widely used for example in the regeneration process of economically important plants ${ }^{48}$ or to obtain commercially valid secondary plant metabolities..$^{49}$

"American Journal of Botany" vol. 45 (1958), p. 705-708.

46 T. Nagata, I. Takebe, Plating of Isolated Tobacco Mesophyll Protoplasts on Agar Medium, "Planta" vol. 99 (1971), p. 12-20; A. Bach, B. Pawłowska, Procesy rozwojowe $w$ kulturach in vitro i typy kultury, op. cit.

${ }^{47}$ F. Skoog, C. O. Miller, Chemical Regulation of Growth and Organ Formation in Plant Tissues Cultured in vitro, op. cit.; R. Goren, A. Altman, I. Giladi, Role of Ethylene in Abscisic Acid-Induced Callus Formation in Citrus Bud Cultures, "Plant Physiology" vol. 63 (1979), p. 280-282.

48 For instance: J. Simonsen, A. C. Hildebrandt, In vitro Growth and Differentiation of Gladiolus Plants from Callus Cultures, "Canadian Journal of Botany" vol. 49 (1971) 10, p. 1817-1819; For instance: K. E. Paterson, N. P. Everett, Regeneration of Helianthus annuus inbred Plants from callus, "Plant Science" vol. 42 (1985) 2 (19), p. 125-132; For instance: G. Góralski, M. Popielarska, H. Ślesak, D. Siwińska, M. Batycka, Organogenesis in endosperm of Actinidia deliciosa cv. Hayward Cultured in vitro, "Acta Biologica Cracoviensia. Series Botanica" vol. 47 (2005) 2, p. 121-128; For instance: M. Wani, S. Pande, N. More, Callus Induction Studies in Tridax procumbens L., "International Journal of Biotechnology Applications" vol. 2 (2010) 1, p. 11-14; For instance: S. Rakshit, Z. Rashid, J. C. Sekhar, T. Fatma, S. Dass, Callus Induction and Whole Plant Regeneration in Elite Indian maize (Zea mays L.) inbreds, "Plant Cell, Tissue and Organ Culture (PCTOC)" vol. 100 (2010) 1, p. 31-37.

${ }^{49}$ For instance: V. Mulabagal, H-S. Tsay, Plant Cell cultures - an Alternative and Efficient Source for the Production of Biologically Important Secondary Metabolites, "International Journal of Applied Science and Engineering" vol. 2 (2004) 1, p. 29-48. 


\subsection{The importance and usefulness of plant in vitro cultures}

There are many areas of plant tissue culture that include experiments on in vitro pollination, ${ }^{50}$ embryo and protoplast ${ }^{51}$ culturing, ${ }^{52}$ receiving endosperm ${ }^{53}$ derived plants, ${ }^{54}$ haploids as well as double haploids, ${ }^{55}$ and many other areas of research. ${ }^{56}$ Pure research done in in vitro cultures may be an output to applied research on

50 For instance: I. Dupuis, C. Dumas, In vitro Pollination as a Model for Studying Fertilization in Maize (Zea mays L.), "Sexual Plant Reproduction" vol. 2 (1989) 4, p. 265-269; For instance: M. Popielarska, In vitro Pollination of Isolated Ovules of Sunflower (Helianthus annus L.), "Acta Biologica Cracoviensia. Series Botanica" vol. 47 (2005) 1, p. 85-92.

${ }^{51}$ Protoplasts are cells without cell walls. They are used to obtain somatic hybrids and consequently interspecific hybrids with new characteristics. See: I. Ślesak, Fuzja protoplastów roślinnych i jej praktyczne znaczenie, „Wiadomości Botaniczne" vol. 41 (1997) 3/4, p. 63-76.

52 For instance: C. C. Eady, R. C. Butler, Y. Suo, Somatic Embryogenesis and Plant Regeneration from Immature Embryo Cultures of Onion (Allium cepa L.), "Plant Cell Reports" vol. 18 (1998) 1-2, p. 111-116; For instance: C. Yu, Z. Chen, L. Lu, J. Lin, Somatic Embryogenesis and Plant Regeneration from Litchi Protoplasts Isolated from Embryogenic Suspensions, "Plant Cell, Tissue and Organ Culture (PCTOC)" vol. 61 (2000) 1, p. 51-58.

${ }^{53}$ Endosperm is a tissue which occurs in seeds. It can be used to produce triploid plants with commercially desirable features. See: T. D. Thomas, R. Chaturvedi, Endosperm Culture: a Novel Method for Triploid Plant Production, "Plant Cell, Tissue and Organ Culture (PCTOC)" vol. 93 (2008), p. 1-14; Y. Hoshino, T. Miyashita, T. D. Thomas, In vitro Culture of Endosperm and its Application in Plant Breeding: Approaches to Polyploidy Breeding, "Scientia Horticulturae", vol. 130 (2011) , p. 1-8.

${ }_{54}$ For instance: G. Góralski, M. Popielarska, H. Ślesak, D. Siwińska, M. Batycka, Organogenesis in Endosperm of Actinidia deliciosa cv. Hayward Cultured in vitro, op. cit.

${ }_{55}$ For instance: Y. P. S. Bajaj, In vitro Production of Haploids and Their Use in Cell Genetics and Plant Breeding, "Biotechnology in Agriculture and Forestry" vol. 12 (1990), p. 3-44; For instance: I. Marcińska, A. Nowakowska, E. Skrzypek, I. Czyczyło-Mysza, Production of Double Haploids in Oat (Avena sativa L.) by Pollination with Maize (Zea mays L.), "Central European Journal of Biology" vol. 8 (2013) 3, p. 306-313.

${ }^{56}$ For instance: P. F. McCabe, Ch. J. Leaver, Programmed Cell Death in Cell Cultures, "Plant Molecular Biology" vol. 44 (2000), p. 359-268; M. Popielarska-Konieczna, M. Kozieradzka-Kiszkurno, M. Tuleja, H. Ślesak, P. Kapusta, I. Marcińska, J. Bohdanowicz, Genotype-Dependent Efficiency of Endosperm Development in Culture of Selected Cereals: Histological and Ultrastructural Studies, "Protoplasma" vol. 250 (2013) 1, p. 361-369. 
plant breeding, the production of natural plant components, or genetic engineering. Numerous in vitro culture studies influence the receiving of new varieties of plants of commercial importance, conservation of endangered species, or understanding of many physiological and genetic aspects. ${ }^{57}$

In the sense of plants propagation, plant in vitro cultures present an opportunity to obtain a large number of new plants from just one source of material in a very short period of time. ${ }^{58}$ This method is especially valid for plants with industrial importance, such as: ornamental, fruited, or forestry ones. It is used for elite plants with high unitary value as well. ${ }^{59}$ In vitro propagation is also a technique used to obtain sowing material for plants like potatoes or cereals. ${ }^{60}$

One of the biggest advantages is that plants received by in vitro culture are free of viral or bacterial diseases. ${ }^{61}$ Moreover, the mass propagation of plants with particularly preferred features is very popular in in vitro cultures. ${ }^{62}$

Plants produce a variety of substances with biological activities that are used by the agricultural, pharmaceutical, or food industries. In this context, in vitro culture is an efficient method for the production of high-value natural plant products. Suspension cultures are in special usage and huge bioreactors have been designed for use on a large commercial scale. ${ }^{63}$

${ }_{57}$ H. R. Dagla, Plant Tissue Culture. Historical Developments and Applied Aspects, op. cit.; A. Bach, B. Pawłowska, Procesy rozwojowe w kulturach in vitro i typy kultury, op. cit.

58 E. F. George, Plant Tissue Culture Procedure - Background, op. cit.

59 A. Bach, B. Pawłowska, Procesy rozwojowe w kulturach in vitro i typy kultury, op. cit.

${ }^{60}$ High-Tech and Micropropagation V, ed. Y. P. S. Bajaj, New Delhi 1997a (Biotechnology in Agriculture and Forestry, 39); High-Tech and Micropropagation VI, ed. Y. P. S. Bajaj, 1997b (Biotechnology in Agriculture and Forestry, 40).

61 I. K. Vasil, A History of Plant Biotechnology: from the Cell Theory of Schleiden and Schwann to Biotech Crops, "Plant Cell Reports" vol. 27 (2008) 9, p. 1423-1440.

62 , "Biotechnology Advances" vol. 18 (2000) 2, p. 91-120.

${ }^{63}$ H. R. Dagla, Plant Tissue Culture. Historical Developments and Applied Aspects, op. cit. 
Plant in vitro cultures are also connected with plant ex situ conservation. ${ }^{64}$ The protection of especially rare and endangered species can be done by the propagation of valuable plants, their introduction into botanic gardens, and then, if possible, to the natural sites. The method of artificial seeds in which fragments of parental plants are used can fulfill this role as well. ${ }^{65}$

Plant in vitro culture techniques are presented in many fields of botany, as has been briefly mentioned above. It should be noted that many studies related to the world of plants would not be possible if in vitro cultures methods have not been used.

\subsection{Do plants feel?}

Much research has reported that plants can communicate and interact with each other. ${ }^{66}$ There are several different ways in which this occurs, such as airborne chemicals, ${ }^{67}$ soluble compounds submitted by roots ${ }^{68}$ or mycelial networks made by mycorrhizal fungi ${ }^{69}$

${ }^{64}$ M. T. Gonzalez-Arnao, A. Panta, W. M. Roca, R. H. Escobar, F. Engelmann, Development and Large Scale Application of Cryopreservation Techniques for Shoot and Somatic Embryo Cultures of Tropical Crops, "Plant Cell, Tissue and Organ Culture (PCTOC)" vol. 92 (2008) 1, p. 1-13.

65 F. Engelmann, J. M. M. Engels, Technologies and Strategies for ex situ Conservation, [in:] Managing Plant Genetic Diversity, ed. J. M. M. Engels, R. Rao, A. H. D. Brown, M. T. Jackson, Oxford 2002, p. 89-104.

${ }^{6}$ A. A. Agrawal, Communication between Plants: this Time It's Real, "Trends in Ecology \& Evolution" vol. 15 (2000), p. 446; R. Karban, I. T. Baldwin, K. J. Baxter, G. Laue, G. W. Felton, Communication between Plants: induced Resistance in Wild Tobacco Plants following Clipping of Neighboring Sagebrush, "Oecologia" vol. 125 (2000), p. 66-71.

${ }^{67}$ I. T. Baldwin, Plant Volatiles, "Current Biology" vol. 20 (2010), p. R392R397.

68 O. Falik, Y. Mordoch, D. Ben-Natan, M. Vanunu, O. Goldstein, A. Novoplansky, Plant Responsiveness to Root-Root Communication of Stress Cues, "Annals of Botany" vol. 110 (2012), p. 271-280.

${ }^{69}$ Z. Babikova, L. Gilbert, T. Bruce, M. Birkett, J. C. Caulfield, Ch. Woodcock, J. Pickett, D. Johnson, Underground Signals Carried through Common Mycelial Networks Warn Neighbouring Plants of Aphid Attack, "Ecology Letters" vol. 16 (2013), p. 835-843; Z. Babikova, D. Johnson, T. Bruce, J. Pickett, L. Gilbert, How Rapid is Aphid-Induced Signal Transfer Between Plants via Common Mycelial Networks?, "Communicative \& Integrative Biology” vol. 6 (2013) 6, no. e25904. 
The role of an effective signaling system is to warn neighboring plants of herbivores, pathogen attacks, or upcoming drought. ${ }^{70} \mathrm{In}$ such a way, plants can recognize their kin and generally receive information from the surrounding environment. ${ }^{71}$

These studies are interesting, but even more interesting are reports on signaling within the plant body. Research conducted by Karpiński and his team ${ }^{72}$ suggests that plants have specialized systems for the transmission of information within their own bodies. Even very remote plant cells can communicate with each other. They can be seen as analogous to the animal nervous system and are a contribution to the discussion of if plants can feel or not and if they have any consciousness.

\section{Philosophical and legal aspects in the case of in vitro cultures}

The main aspects of the in vitro procedure that have been presented in the first part of the paper lead to the following conclusion: there is a set of performed biological experiments and research that are based on interventions into the plant: the organism. This fact, however, does not raise doubts of an axiological, ethical, or legal nature. Prima facie such a state of affairs seems to be natural

70 O. Falik, Relay Communication of Stress Cues in Plants, "PLoS ONE" vol. 6 (2011) 11, no. e23625; S. A. Zebelo, M. E. Maffei, Role of Early Signalling Events in Plant-Insect Interactions, "Journal of Experimental Botany" vol. 66 (2015) 2, p. 435-448.

71 S. A. Dudley, A. L. File, Kin Recognition in an Annual Plant, "Biology Letters" vol. 3 (2007), p. 435-438; G. P. Murphy, S. A. Dudley, Kin Recognition: Competition and Cooperation in Impatiens (Balsaminaceae), "American Journal of Botany" vol. 96 (2009), p. 1990-1996.

72 See: S. Karpiński, H. Reynolds, B. Karpińska, G. Wingsle, G. Creissen, P. Mullineaux, Systemic Signaling and Acclimation in Response to Excess Excitation Energy in Arabidopsis, "Science" vol. 284 (1999) 5414, p. 654-657; see: M. Szechyńska-Hebda, J. Kruk, M. Górecka, B. Karpińska, S. Karpiński, Evidence for Light Wavelength-Specific Photoelectrophysiological Signaling and Memory of Excess Light Episodes in Arabidopsis, “The Plant Cell” vol. 22 (2010) 7, p. 22012218 . 
and obvious: considering the philosophical and, all the more, legal aspects of such procedures, they may be evaluated as redundant or premature and inappropriate; there exists no "ethical code" neither in in vitro cultures nor in plant experiments in general. Such procedures like callus induction or protoplast culturing mentioned in the previous part, which are based on drastic interventions into the plant cell or "body", are conducted every day in thousands of laboratories in the world.

Our aim, of course, is not to negate such position and attitude. The intention of this text is definitely not so ambitious; our point is merely to indicate possible, future ways of change of our attitude to plants. Nowadays, such problems are relatively rarely discussed, but, on the other hand, the Swiss government has created a special ethical commission ${ }^{73}$ whose purpose is to debate about possible regulations protecting plants for their own sake and some philosophers (certain representatives of such a philosophical paradigm will be indicated later in article) have signaled such problems since 1970.

Before we discuss some philosophical propositions and their possible legal implications, there is a need to portray a simple thought experiment, which perhaps will explain the character of our philosophical considerations and will legitimate the proposed way of analysis. We shall start with ascertaining some facts. Consider people's attitude to animals in our world 200 years ago. It has radically changed: from the commonly accepted view that humans are the only beings capable to feeling pain, our philosophical attitude and scientific knowledge have evolved to the contemporary view that animals are capable of feeling pain and therefore we have to limit situations which cause such feelings.

This descriptively normative statement would be probably rejected as "simply silly" or, at least, "revolutionary". Although we do not have knowledge that lets us fully explain the nature of

73 One of the relevant documents is: The Dignity of Living Beings with regard to Plants. Moral consideration of Plants for Their Own Sake, Switzerland 2008, http://www.ekah.admin.ch/fileadmin/ekah-dateien/dokumentation/publikationen/ e-Broschure-Wurde-Pflanze-2008.pdf (15.02.2015). 
such feelings, we decide to protects animals and make special legal norms concerning certain situations.

Now, we will introduce an element characteristic for contemporary debates in analytical philosophy: imagine that we live in other possible world, which is an ideal copy of ours, but 100 years later. People have gained new knowledge, relevantly extended in comparison to of people living in 2015, among others concerning the character of plant's feeling of pain. Although there is no common opinion about the nature of such feeling, it raises no doubts in numerous aspects analogical to the way animal are in pain; therefore, the actual knowledge is appraised as sufficient to recognize the necessity of legal protection of plants.

The reasoning leading to legislative actions in the case of animals was then as follows:

1) a change of the ethical model: we assume that animals are also able to feel pain; then, we infer that we have some moral duties to animals/plants; as a consequence

2) the change of axiology: the welfare of animals is perceived as a value; it causes:

3) legal change (change of specific legal regulations): since the well-being of the animal is a moral value, there is a need for the introduction of certain legal norms. ${ }^{74}$

Such schema may be treated as a model way of creating certain group of legal regulation.

Our claim is not that plants deserve this kind of protection, but neither is that they do not deserve it. Answering this question is beyond the scope of this paper and shall be predated by sophisticated research. Instead, we would like to consider whether the word "animal" in the aforementioned three sentences can be replaced in a justified way with the word "plant" and which consequences of such change may be evaluated as relevant from the perspective of in vitro cultures experiments. Therefore, our purpose is to

${ }^{74}$ We are aware of significant simplification we make by such describing the process of creating legal norms. However, we hope it is warrantable by the character of the present paper. 
signalize possible ethical controversies concerning the biological experiments in general, and the case of in vitro cultures perfectly serves as an example.

\subsection{Philosophical conceptions of the (eventual) axiology of plants and their possible practical (legal) implications}

In contemporary philosophy, the axiological approach to the nature of plants certainly is not one of main problems canvassed between numerous thinkers. It does not mean, however, that publications that have appeared in last decades are not worth pointing. What is important from the viewpoint of legitimating of such a research program is that prestigious universities and publishers published some of them.

In the present part, we will consider three ways of interpretation of the eventual axiology. The first model, which we will call the "separationist" model, is probably the most intuitive one and is shared by great number of philosophers and biologists. According to this "way of thinking", there is no similarity between animals and plants in the aspects relevant from the axiological perspective and their moral rights. Second, the "equalist" model presupposes the existence of certain similarities between animals and plants and therefore its proponents ascertain that plants may deserve some of the protection animals have nowadays. It is also possible to indicate more radical versions; some authors postulate the axiological and moral equality of plants and animals and, sometimes, even the necessity of treating plants as persons. ${ }^{75}$

The first model will not be explicated in detail; it is a simple rejection of tendencies concerning ascribing any kind of value to the life of plants. As has been stated, such a position is implicitly accepted by all researchers who conduct experiments similar to in vitro procedures described in the first part of paper. Such a method does not raise ethical or axiological questions. It was briefly

75 In certain aspects see: M. Hall, Plants as Persons. A Philosophical Botany, Albany (NY) 2011. 
described by Swiss Federal Ethics Committee on Non-Human Biotechnology in the document entitled "The Dignity of Living Beings with Regard to Plants: Moral consideration of plants for their own sake", published in 2008, in the following way:

For some people, the question of whether the treatment or handling of plants requires moral justification is a meaningless one. The moral consideration of plants is considered to be senseless [...]. In their view, the human treatment of plants is on morally neutral ground and therefore requires no justification. ${ }^{76}$

There are many reasons for the acceptance of this view. It is congruent with the common moral intuitions, but such compatibility is obviously not sufficient for philosophical analysis. Two arguments present in the discourse are therefore worth pointing to in this place.

According to the first one, one can create a pragmatic argument: life would be too complicated if using plants for various aims had to be justified on a moral basis. Such an argument seems to be really weak and defeasible. The second, more sophisticated one is that "ethical positions that value plants for their own sake could relativize higher-weighted moral responsibilities towards humans (and animals)". ${ }^{77}$ It is debatable whether the recognition of plant's value gives rise to such doubts; instead, it extends the area of human's responsibility. The relativization is, of course, one of the side effects, but it is doubtful whether should be evaluated as negative. ${ }^{78}$ Eventually, the most important reason is probably that although there are certain indications that plants are able to feeling pain, as has been previously stated (in the part "Do plants feel?"), the character of such pain is a mystery and we do not know if it should

76 See: The Dignity of Living Beings with Regard to Plants. Moral Consideration of Plants for Their Own Sake, Switzerland 2008, p. 4, http://www.ekah.admin.ch/fileadmin/ekah-dateien/dokumentation/publikationen/e-Broschure-WurdePflanze-2008.pdf (15.02.2015).

77 The Dignity of Living Beings with Regard to Plants, op.cit.

78 The Dignity of Living Beings with Regard to Plants, op.cit. 
be recognized as sufficient for axiological and legal conclusions concerning the experimental botany. Nowadays, this problem is crucial in formulating an ethical and axiological approach to, for instance, plant in vitro cultures.

Some of the second model's proponents go further. Generally, they claim the need for taking into consideration the character of plants in the holistic perspective. Plants become one part of the whole environment and, therefore, need protection in certain aspects similar to the protection of animals or humans. Philosopher Paul Taylor from City University of New York has proposed the concept of "inherent worth". ${ }^{79}$

His aim is to "construct and defend a theory of environmental ethics that does not rely on the idea of rights". ${ }^{80}$ Indeed, the term "plant's rights" appears not only as controversial one, but rather commonly unacceptable, especially in the context of discussions concerning "animal rights". He asserts that having such worth is sufficient to recognize them as part of moral community. On the other hand, however, Taylor's opinion is that it is not a necessary prerequisite for creating legal rights of plants to ascribe them moral rights, when he writes: "It is possible to argue for making animals and plants bearers of legal rights without claiming that they have moral rights" ${ }^{81}$

Such a statement may be interpreted in many ways. Independently from Taylor's way of understanding, such an approach seems to be moderate, but also revolutionary (sic!). It may be treated as moderate because it does not require the revolutionary change of common morality; it is revolutionary because it allows us to introduce relevant modifications to the law. Michael Marder's position is similar in numerous aspects. He writes:

There is no doubt that plants are some of the most vulnerable living beings on the planet: even according to fairly conservative estimates,

79 P. Taylor, Respect for Nature, Princeton (NJ) 2011, p. 71.

80 P. Taylor, Respect for Nature, op. cit., p. 219.

81 P. Taylor, Respect for Nature, op. cit., p. 224. 
one in every five plant species is currently on the brink of extinction. Given this disastrous global situation, the protection of their rights could serve as a useful legal mechanism for decelerating the loss of biodiversity and mitigating the destruction of the flora, the cornerstone of any natural environment. ${ }^{82}$

He is aware of the fancifulness of "plant rights" idea. ${ }^{83}$ The aim of such moral and legal institutions will be merely as follows: it will probably curtail the negative effects of human activity and its impact on plant life. ${ }^{84}$ An extension of rights to the flora would, at minimum, curtail our negative impact on plant life.

In summation, one can easily observe a lack of common opinion concerning the criterion of moral duties existence in contemporary philosophical discussions. On the other hand, the representatives of various philosophical positions express one common opinion, according to which there is a need of considering some legal changes. These will be considered below.

According to the model portraying the relation between recognizing value, formulating the moral obligation to preserve it, and articulating de lege ferenda postulates, one can reconstruct some proposals concerning the legal regulation of plant's status, which will be relevant from the perspective of, for instance, in vitro research.

Firstly, in the context of the currently dominant view - which we called "separationist" - there is no need for making new legal regulations. Plants are not to be treated as subjects of rights for their own sake; hence legal norms "protecting" them are redundant.

Secondly, in the light of "moderate" view, some proposed legal changes concerning the issue of plants' protection are worth considering. As Taylor notices:

${ }^{82}$ M. Marder, Should Plants Have Rights?, "The Philosopher's Magazine" 62 (2013), p. 47.

83 M. Marder, Should Plants Have Rights?, op. cit., p. 47.

84 M. Marder, Should Plants Have Rights?, op. cit., p. 47. 
As long as we consider animals and plants to be entities that have a good of their own which can be furthered or damaged by the actions of human agents, it is logically conceivable for them to have the legal status of bearer-of-rights in a given society. Thus we can speak meaningfully of protecting their good by laws that entitle them to be treated in certain ways. Just as is the case with humans, their life and well-being can be made secure by laws that confer on them certain rights. ${ }^{85}$

As has been previously stated, such regulations may be handled as a tool serving the enhancement of the protection of all plants, regardless of their moral status. Similar positions may be inferred from Melder's conception. Such a pragmatic attempt seems to be generally uncontroversial and is not relevant from the viewpoint of experimental biology. It would be difficult to imagine that this kind of regulation would limit the rights of researchers and scholars.

Eventually, the approach presented, for instance, by Stone is also worth noting, as it implies far-reaching consequences in the area of law, which are unacceptable from the point of view of the contemporary legal system as well as attitudes of the members of the scientific societies. As he fairly notes:

I am quite seriously proposing that we give legal rights to forests, oceans, rivers and other so-called "natural objects" · in the environment-indeed, to the natural environment as a whole. As strange as such a notion may sound, it is neither fanciful nor devoid of operational content. In fact, I do not think it would be a misdescription of recent developments in the law to say that we are already on the verge of assigning some such rights, although we have not faced up to what we are doing in those particular terms. We should do so now, and begin to explore the implications such a notion would hold. ${ }^{86}$

85 P. Taylor, Respect for Nature, op. cit., p. 222.

86 C. D. Stone, Environmental Legal Rights, „Southern California Law Review” 45 (1972), pp. 456-457. 
If such view will be accepted in the future, all experiments similar to in vitro procedures will be evaluated as impermissible. Consequently, an eventual lack of legal norms regulating the relation between humans and plants (and, inter alia, the possibility of experiments similar to in vitro) will be appraised as wrong.

Obviously, these days we cannot assert whether that kind of position will ever be acceptable for the members of philosophical and scientific community. For contemporary scholars it is still "unthinkable", as Stone had described predicted reactions for his paper more than 40 years ago. But, perhaps, it is just a matter of time, and in the coming 50 years radical propositions will be part of set of legal norms and will be apparent and beyond disputes?

\section{Resume}

In the first part of the paper, we portray some issues related to the character of biological experiments conducted under in vitro cultures. The relevant aspects of these procedures are briefly explicated. It serves as a case study for the considerations in the second part, which presents selected philosophical and legal issues involved in biological experiments from the general perspective of philosophical investigations concerning the problem of plants' axiology. Obviously, our considerations are of strictly limited character. Not all important questions from the perspective of biology have been raised. Nevertheless, we hope that analyzed issues may be interesting for both biologists and philosophers.

\section{Summary}

\section{Considerations on legal and philosophical problems in} experimental botany: case of plant in vitro cultures

The present paper consists of two parts. In the first, some issues related to the character of biological experiments conducted under in vitro cultures are portrayed. The relevant aspects of these procedures are explicated from the viewpoint of the experimental botanist. It is a case study for the considera- 
tions in the second part, which presents selected philosophical and legal issues involved in biological experiments from the general perspective of philosophical investigations concerning the problem of plants' axiology. Obviously, the nature of the considerations is limited; not all important questions from the perspective of biology and philosophy have been raised. Nevertheless, the authors hope that the analyzed issues may be interesting for both biologists and philosophers.

Keywords experimental botany, in vitro cultures, plant's axiology, scientific experiments and law.

\section{Bibliography}

Adamczuk A., Siegień I., Ciereszko I., Morphogenesis of Plants in vitro under Stress Conditions, [in:] Biological Diversity - from Cell to Ecosystem, ed. G. Łaska, Białystok 2012.

Agrawal A. A., Communication between Plants: this Time It's Real, "Trends in Ecology \& Evolution” vol. 15 (2000).

Babikova Z., Gilbert L., Bruce T., Birkett M, Caulfield J. C., Woodcock Ch., Pickett J., Johnson D., Underground Signals Carried through Common Mycelial Networks Warn Neighbouring Plants of Aphid Attack, "Ecology Letters" vol. 16 (2013), p. 835-843.

Bach A., Pawłowska B., Procesy rozwojowe w kulturach in vitro i typy kultury, [in:] Biotechnologia roślin, red. S. Malepszy, Warszawa 2009.

High-Tech and Micropropagation V, ed. Y. P. S. Bajaj, New Delhi 1997a (Biotechnology in Agriculture and Forestry, 39).

High-Tech and Micropropagation V, ed. Y. P. S. Bajaj, New Delhi 1997b (Biotechnology in Agriculture and Forestry, 40).

Bajaj Y. P. S., In vitro Production of Haploids and Their Use in Cell Genetics and Plant Breeding, "Biotechnology in Agriculture and Forestry" vol. 12 (1990), p. 3-44.

Baldwin I. T., Plant Volatiles, "Current Biology" vol. 20 (2010), p. R392-R397.

Ball E., Development in Sterile Culture of Stem Tips and Subjacent Regions of Tropaeolum majus L. and of Lupinus albus L., "American Journal of Botany" vol. 33 (1946) 5, p. 301-318.

Bhojwani S. S., Razdan M. K., Plant Tissue Culture: Theory and Practice, a revised edition, New Delhi 2004. 
Cassells A. C., Doyle B. M., Pathogen and Biological Contamination Management: the Road Ahead, [in:] Plant Cell Culture Protocols, ed. V. M. Loyola-Vargas, F. Vázquez-Flota, New York 2005, p. 35-50.

Christianson M. L., Warnick D. A., Temporal Requirement for Phytohormone Balance in the Control of Organogenesis in vitro, "Developmental Biology" vol. 112 (1985), p. 494-497.

Dagla H. R., Plant Tissue Culture. Historical Developments and Applied Aspects, "Resonance" vol. 17 (2012) 8, p. 759-767.

Dudley S. A., File A. L., Kin Recognition in an Annual Plant, "Biology Letters" vol. 3 (2007), p. 435-438.

Eady C. C., Butler R. C., Suo Y., Somatic Embryogenesis and Plant Regeneration from Immature Embryo Cultures of Onion (Allium cepa L.), "Plant Cell Reports" vol. 18 (1998) 1-2, p. 111-116.

Engelmann F., Engels J. M. M., Technologies and Strategies for ex situ Conservation, [in:] Managing Plant Genetic Diversity, ed. J. M. M. Engels, R. Rao, A. H. D. Brown, M. T. Jackson, Oxford 2002, p. 89-104.

Falik O., Mordoch Y., Ben-Natan D., Vanunu M., Goldstein O., Novoplansky A., Plant Responsiveness to Root-Root Communication of Stress Cues, "Annals of Botany" vol. 110 (2012), p. 271-28.

Falik O., Mordoch Y., Quansah L., Fait A., Novoplansky A., Rumor Has It...: Relay Communication of Stress Cues in Plants, "PLoS ONE" vol. 6 (2011) 11, no. e23625.

Gonzalez-Arnao M. T., Panta A., Roca W. M., Escobar R. H., Engelmann F., Development and Large Scale Application of Cryopreservation Techniques for Shoot and Somatic Embryo Cultures of Tropical Crops, "Plant Cell, Tissue and Organ Culture (PCTOC)" vol. 92 (2008) 1, p. 1-13.

Goren R., Altman A., Giladi I., Role of Ethylene in Abscisic Acid-Induced Callus Formation in Citrus Bud Cultures, "Plant Physiology" vol. 63 (1979), p. 280-282.

Gorst J. R., The Concept of Totipotency, [in:] Plants in Action. Adaptation in Nature, Performance in Cultivation, ed. B. J. Atwell, P. E. Kriedemann, C. G. N. Turnbull, Melbourne 1999, http://plantsinaction.science.uq.edu. $\mathrm{au} /$ edition $1 /$ ? $\mathrm{q}=$ content/10-2-1-concept-totipotency (17.03.2015).

Hall M., Plants as Persons. A Philosophical Botany, Albany (NY) 2011.

Haq I., Chang-Xing Z., Mukhtar Z., Jaleel C. A., Azooz M. M., Effect of Physical Desiccation on Plant Regeneration Efficiency in Rice (Oryza sativa L.) Variety super basmati, “Journal of Plant Physiology” vol. 166 (2009). 
Harrison J. H., Foreword, [in]: Experiment in Plant Tissue Culture, ed. J. H. Dodds, L. W. Roberts, New York 1985.

How Rapid is Aphid-Induced Signal Transfer Between Plants via Common Mycelial Networks?, "Communicative \& Integrative Biology” vol. 6 (2013) 6, no. e25904.

Ikeuchi M., Sugimoto K., Iwase A., Plant Callus: Mechanisms of Induction and Repression, "The Plant Cell”, vol. 25 (2013), p. 3159-3173.

Karban R., Baldwin I. T., Baxter K. J., Laue G., Felton G. W., Communication between Plants: induced Resistance in Wild Tobacco Plants following Clipping of Neighboring Sagebrush, "Oecologia” vol. v. 125 (2000), p. 66-71.

Karpiński S., Reynolds H., Karpińska B., Wingsle G., Creissen G., Mullineaux P., Systemic Signaling and Acclimation in Response to Excess Excitation Energy in Arabidopsis, "Science" vol. 284 (1999) 5414, p. 654-657.

Khanna H. K., Daggard G. E., Enhanced of Shoot Regeneration in Nine Australian Wheat Cultivars by Spermidine and Water Stress Treatments, "Australian Journal of Plant Physiology" vol. 28 (2001), p. 1243-1247.

Kozai T., Kubota C., Jeong B. R., Environmental Control for the Large-Scale Production of Plants through in vitro Techniques, "Plant Cell, Tissue and Organ Culture (PCTOC)” vol. 51 (1997) 1, p. 49-56.

Marcińska I., Nowakowska A., Skrzypek E., Czyczyło-Mysza I., Production of Double Haploids in Oat (Avena sativa L.) by Pollination with Maize (Zea mays L.), "Central European Journal of Biology" vol. 8 (2013) 3, p. 306-313.

Marder M., Should Plants Have Rights?, "The Philosopher's Magazine" 62 (2013).

Matysiak K., Adamczewski K., Regulatory wzrostu i rozwoju roślin - kierunki badań w Polsce i na świecie, „Progress in Plant Protection” vol. 49 (2009) 4, p. 1810-1816.

McCabe P. F., Leaver C. J., Programmed Cell Death in Cell Cultures, "Plant Molecular Biology" vol. 44 (2000), p. 359-268.

Murashige T., Skoog F., A Revised Medium for Rapid Growth and Bio-Sssays with Tobacco Tissue Cultures, "Physiologia Plantarum", vol. 15 (1962), p. 473-497.

Murphy G.P., Dudley S. A., Kin Recognition: Competition and Cooperation in Impatiens (Balsaminaceae), "American Journal of Botany" vol. 96 (2009), p. 1990-1996. 
Nagata T., Takebe I., Plating of Isolated Tobacco Mesophyll Protoplasts on Agar Medium, "Planta" vol. 99 (1971), p. 12-20.

Phillips G. C., In vitro morphogenesis in plants - recent advances, "In Vitro Cellular \& Developmental Biology - Plant” vol. 40 (2004), p. 342-345.

Popielarska-Konieczna M., Kozieradzka-Kiszkurno M., Tuleja M., Ślesak H., Kapusta P., Marcińska I., Bohdanowicz J., Genotype-Dependent Efficiency of Endosperm Development in Culture of Selected Cereals: Histological and Ultrastructural Studies, "Protoplasma" vol. 250 (2013) 1, p. 361-369.

Puijalon S., Piola F., Bornette G., Abiotic Stresses Increase Plant Regeneration Ability, "Evolutionary Ecology" vol. 22 (2008), p. 493-506.

Jain R. K., Jain S., Wu R., Stimulatory Effect of Water Stress on Plant Regeneration in Aromatic Indica Rice Varieties, "Plant Cell Reports" vol. 15 (1996), p. 449-454.

Rout G. R., Samantaray S., Das P., In vitro Manipulation and Propagation of Medicinal Plants, "Biotechnology Advances", vol. 18 (2000) 2.

Schleiden M. J., Beiträge zur Phytogenesis, Berlin 1838 (Archiv für Anatomie, Physiologie und Wissenschaftliche Medicin, von. J. Müller).

Schwann T., Mikroscopische Untersuchungen über die Übereinstimmung in der Struktur und dem Wachstum des Thiere und Pflanzen, von W. Engelmann, Leipzig 1839.

Plant Propagation by Tissue Culture, 3rd Edition, Volume 1. The Background, ed. E. F. George, M. A. Hall, G.-J. de Klerk, The Netherlands 2008.

Skoog F., Miller C. O., Chemical Regulation of Growth and Organ Formation in Plant Tissues Cultured in vitro, "Symposia of the Society for Experimental Biology" vol. 11 (1957), p. 118-130.

Ślesak I., Libik M., Karpińska B., Karpiński S., Miszalski Z., The Role of Hydrogen Peroxide in Regulation of Plant Metabolism and Cellular Signalling in Response to Environmental Stresses, "Acta Biochimica Polonica" vol. 54 (2007), p. 39-50.

Steward F. C., Mapes M. O., Mears K., Growth and Organized Development of Cultured Cells. II. Organization in Cultures Grown from Freely Suspended Cells, “American Journal of Botany” vol. 45 (1958), p. 705-708.

Stone C. D., Environmental Legal Rights, „Southern California Law Review” 45 (1972), pp. 456-457.

Sussex M., The Scientific Roots of Modern Plant Biotechnology, "The Plant Cell" vol. 20 (2008) 5, p. 1189-1198. 
Szechyńska M. Szechyńska-Hebda, J. Kruk, M. Górecka, B. Karpińska, S. Karpiński, Evidence for Light Wavelength-Specific Photoelectrophysiological Signaling and Memory of Excess Light Episodes in Arabidopsis, "The Plant Cell" vol. 22 (2010) 7, p. 2201-2218.

Taylor P., Respect for Nature, Princeton (NJ) 2011.

Tretyn A., Podstawy strukturalno-funkcjonalne komórki roślinnej, [in:] Fizjologia roślin, red. J. Kopcewicz, S. Lewak, Warszawa 2012, p. 22-84.

Yu C., Chen Z., Lu L., Lin J, Somatic Embryogenesis and Plant Regeneration from Litchi Protoplasts Isolated from Embryogenic Suspensions, "Plant Cell, Tissue and Organ Culture (PCTOC)" vol. 61 (2000) 1, p. 51-58.

Vasil I. K., A History of Plant Biotechnology: from the Cell Theory of Schleiden and Schwann to Biotech Crops, "Plant Cell Reports" vol. 27 (2008) 9, p. $1423-1440$.

Zebelo S. A., Maffei M. E., Role of Early Signalling Events in Plant-Insect Interactions, "Journal of Experimental Botany" vol. 66 (2015) 2, p. 435-448.

Zenkteler M., Zenkteler E., 65 years of in vitro Culture in Poland, "Acta Societatis Botanicorum Poloniae", vol. 82 (2013) 3, p. 183-192. 